at every stage, the accuracy of the final picture was increased by having means of temperature at several places.

The results are set out in 74 plates, the mean air movement being taken up to $8 \mathrm{~km}$. The main features of the upper wind and temperature distribution in the different months are discussed and then summarized (pp. 192-207). The most striking feature of the circulation is the regular seasonable movement of the upper wind system, which in the summer half of the year is from south-east to north-west and back, and in the remainder of the year is mainly from north to south and back. The smallness of the month to month movement from December to April or May is taken to signify that cooling and heating of the ground over India by radiation does not greatly modify the circulation, the big changes being caused by the northward penetration and the subsequent retreat of moist air from the southern hemisphere with its attendant rainfall.

Other striking features brought out by this study are the modifying influence of the Himalayas up to a height of $6 \mathrm{~km}$., and the fact that regions of heavy rainfall become regions of high temperature and divergence of air movement above $6 \mathrm{~km}$. The mean winds derived from cloud movement have a much larger northward component than those derived from pilot balloons, which last require absence of cloud so that the balloon can be followed. A true picture of average conditions cannot therefore be obtained from either method alone.

\title{
ECONOMICS OF WAR-TIME EXPORT TRADE
}

A VALUABLE broadshret "Exports in War" issued by Political and Economic Planning (P E P) reviews the question in relation to the economics of war and the principles upon which the export policy of Great Britain should be based. The object of exporting at all is to save man-hours, and in war-time to avoid mortgaging the future by the sale of overseas securities. Because of our limited ability to pay for imports in exports or foreign securities and our restricted capacity to ship them over, there must be discrimination between different types of demand for imports, giving priority to those which are most urgent from the point of view of winning the war.

The broadsheet stresses the basic importance of applied intelligence in exports; in war, it is particularly important to concentrate on those goods the selling price of which includes least matter and most mind, and the seller's market which is being created by the War should be utilized to grade up export industries instead of clinging to older and less profitable lines. Similarly, every opportunity missed. of improving productive efficiency is a drag on the national effort. If new layers of demand are continually tapped and labour and capital progressively transferred to more and more advanced processes or products, the shrinkage of formerly important export industries can be faced without dismay. Moreover, if we make the inter-allied economic arrangements between France and Great Britain work effectively, we shall not only have won the war but made also the greatest possible contribution towards winning the peace.

These agreements between France and Great Britain are outstanding among the actual War-time economic measures. With the joint committees on economic co-operation covering the supply and purchase of munitions, food and raw materials, shipping policy and economic warfare, they should lead to one economic policy for the two countries. This is specially true of exports. The three major elements in any export policy are the export potential, the available markets and the foreign trade policies. The nature of the export potential is the most important in a sellers' market, but exports cannot be left to take care of themselves after the needs of the armed forces and of the civilian population have been met, but must be recognized as a priority of the first importance. Among the opportunities for expansion of our exports at present, the broadsheet stresses those in machinery to complete unfinished German contracts, and those in cotton textiles, locomotives and coal.

The effect of the contraband control on export policy must next be recognized. The purpose of such control is to impede the supply of vital commodities to the enemy. This has now been extended to exports, so that Germany's direct overseas trade should soon be virtually destroyed. Particularly in Latin America, the control has created new markets for Great Britain, and for this our bargaining position is in general strong.

The second aspect of economic warfare consists in the extension of the effects of the blockade to the Continent, so as to cripple Germany's trade with those neutrals with whom contact can still be maintained. The object of promoting British exports to European countries is to turn the tide of trade heavily against Germany by raising the prices of neutral products. This involves a careful study of the strategy of economic warfare, if Germany is to be prevented from importing from neighbouring countries. Strategic purchases, for example, of Rumanian oil involve British exports to pay for them. Sound export policies, moreover, can only be framed after the fullest information about markets and resources has been obtained, and such policy covers every aspect of exporting from production to marketing, including the use of bilateral or multilateral methods of approach to markets, import or export subsidies.

A large-scale purchasing programme makes a survey of the export potential more urgent, and the existence of these Anglo-French programmes is an important factor for world producers. Overseas Governments will require to know that resources are available to supply the necessary goods if they are to continue to sell to Britain, and also that exports have priority over alternative demands. The importance of paying sufficient attention to the needs of the non-self-governing colonies is stressed in the broadsheet, which adds one further plea to the many already advanced for a co-ordinator of trade policy with sufficient political status, including access to the Cabinet, to secure the full and coherent use of Great Britain's immense resources for acting as a centre of world economic expansion. 